\title{
ArcheoSciences
}

Revue d'archéométrie

\section{Embalming as a Source of Contamination for Radiocarbon dating of Egyptian Mummies: On a New Chemical Protocol to Extract Bitumen}

L'embaumement comme une source de contamination pour la datation radiocarbone de momies égyptiennes : vers un nouveau protocole chimique pour extraire le bitume

Anita Quiles, Emmanuelle Delqué-Količ, Ludovic Bellot-Gurlet, Clothilde Comby-Zerbino, Matthieu Ménager, Céline Paris, Christelle Souprayen, Cathy Vieillescazes, Guillemette Andreu-Lanoë and Karine Madrigal

\section{(2) OpenEdition}

\section{Electronic version}

URL: https://journals.openedition.org/archeosciences/4222

DOI: 10.4000/archeosciences.4222

ISBN: 978-2-7535-3691-3

ISSN: $2104-3728$

Publisher

Presses universitaires de Rennes

Printed version

Date of publication: 30 November 2014

Number of pages: 135-149

ISBN: 978-2-7535-3689-0

ISSN: $1960-1360$

\section{Electronic reference}

Anita Quiles, Emmanuelle Delqué-Količ, Ludovic Bellot-Gurlet, Clothilde Comby-Zerbino, Matthieu Ménager, Céline Paris, Christelle Souprayen, Cathy Vieillescazes, Guillemette Andreu-Lanoë and Karine Madrigal, "Embalming as a Source of Contamination for Radiocarbon dating of Egyptian Mummies: On a New Chemical Protocol to Extract Bitumen", ArcheoSciences [Online], 38 | 2014, Online since 30 November 2016, connection on 01 February 2022. URL: http://journals.openedition.org/ archeosciences/4222 ; DOI: https://doi.org/10.4000/archeosciences.4222 


\title{
Embalming as a Source of Contamination for Radiocarbon dating of Egyptian Mummies: On a New Chemical Protocol to Extract Bitumen
}

\author{
L'embaumement comme une source de contamination pour la datation radiocarbone \\ de momies égyptiennes : vers un nouveau protocole chimique pour extraire le bitume
}

\author{
Anita Quilesa, b, Emmanuelle Delqué-Količ ${ }^{\mathrm{b}}$, Ludovic Bellot-Gurlet ${ }^{\mathrm{d}}$, \\ Clothilde Comby-Zerbino ${ }^{b}$, Matthieu Ménager ${ }^{\mathrm{d}}$, Céline Paris ${ }^{\mathrm{c}}$, \\ Christelle Souprayen ${ }^{b}$, Cathy Vieillescazes ${ }^{d}$, Guillemette Andreu-Lanö̈ ${ }^{e}$ \\ and Karine MADRIGAL ${ }^{\mathrm{f}}$
}

\begin{abstract}
Radiocarbon dating of Egyptian mummies could be challenged by embalming materials, especially bitumen which is attested in textual sources as being used during the Late Period. Six Egyptian mummies held at the Musée des Confluences in Lyon (France) have been radiocarbon dated, among which two embalmed mummies have given results older than expected, both on textile and organic material (flesh/skin). Radiocarbon dates' ageing relates to the use of a radiocarbon depleted material that is not extracted by classical radiocarbon chemical pre-treatment. In this study, the presence of bitumen is corroborated by infrared spectroscopy analyses. The present paper describes the research we employed to extract bitumen from mummies' linen wrappings. An experimental protocol has been developed and tested on modern linen textiles; it divides into four steps: textile soaking in bitumen - linen samples thermal degradation - extraction protocol - infrared analyses and radiocarbon dating at each step. Test-samples show that bitumen has been correctly extracted only on samples that have not been artificially aged, others remain radiocarbon depleted. Presently, the protocol is not efficient enough to be applied on archaeological samples. The difficulty does not rely on the bitumen present, but on the interactions developed between bitumen and linen fibres over time. Further perspectives and on-going research's steps will also be described that enabled this study to restore these mummies to their chronological context.
\end{abstract}

Résumé : Certains matériaux utilisés dans des protocoles d'embaumement de momies égyptiennes peuvent fausser leur datation radiocarbone; c'est en particulier le cas du bitume dont l'utilisation est attestée par des sources textuelles pour la période tardive. Six momies égyptiennes conservées au Musée des Confluences de Lyon (France) ont été datées par le radiocarbone, parmi elles, deux momies embaumées ont donné des résultats plus vieux qu'attendus à la fois pour des échantillons de textiles et de matières organiques (peau/chair). Ce vieillissement des datations radiocarbone révèle la présence d'un produit appauvri en ${ }^{14} \mathrm{C}$ qui n'a pas été correctement extrait par le protocole de pré-traitement chimique classique. La présence de bitume a été confirmée par des analyses en spectroscopie infrarouge. L'étude présentée décrit l'état des recherches menées pour extraire ce bitume d'échantillons de bandelettes de lin. Un protocole expérimental en quatre étapes a été développé et testé sur des échantillons de tissu de lin modernes : imbibition du tissu dans du bitume - vieillissement artificiel des échantillons de lin - protocole d'extraction - analyses infrarouge et datations radiocarbone. Les résultats obtenus sur les échantillons-tests montrent que le bitume a été correctement extrait des échantillons qui n’ont pas été vieillis artificiellement, mais que les autres restent appauvris en ${ }^{14} C$.

a Pôle d'archéométrie, Institut Français d'Archéologie Orientale, 37 rue al-Cheikh Aly Youssef B.P. Qasr el-Ayni 115211441 Le Caire, Égyte. (aquiles@ifao.egnet.net)

${ }^{\mathrm{b}}$ Laboratoire de Mesure du Carbone 14, CEA Saclay (CEA/CNRS/IRNS/IRD/Ministère de la Culture et de la Communication), bât 450, Porte 4E, 91191 Gif-Sur-Yvette Cedex, France.

"Sorbonne Universités, UPMC Université Paris 6, MONARIS « de la Molécule aux Nano-objets : Réactivité, Interactions et Spectroscopies ", UMR 8233, UPMC-CNRS, 4 place Jussieu, 75252 Paris Cedex 5, France.

d Équipe Ingénierie de la restauration des patrimoines naturel et culturel, Institut Méditerranéen de Biodiversité et d'Ecologie marine et continentale (IMBE) - UMR 7263 CNRS - IRD, Université d'Avignon et des Pays de Vaucluse, 33, rue Louis-Pasteur, 84000 Avignon, France.

'Département des antiquités égyptiennes, musée du Louvre, 75058 Paris Cedex 01, France.

${ }^{\mathrm{f}}$ Musée des Confluences de Lyon, 28 boulevard des Belges, 69006 Lyon, France. 
Actuellement, ce protocole n'est donc pas suffisant pour être appliqué à des échantillons archéologiques; la diffculté n'est pas liée à la présence de bitume mais aux interactions mises en jeu entre le bitume et les fibres de lin au cours du temps. De nouvelles perspectives de travail seront finalement détaillées pour mener cette étude jusqu'à restaurer ces momies dans leur contexte chronologique.

Keywords: bitumen, Egyptian mummies, embalming ritual, extraction protocol, Infrared Spectroscopy, radiocarbon dating

Mots clés : bitume, datation par le carbone 14, momies égyptiennes, protocole d'extraction, rituel d'embaumement, spectroscopie infrarouge

\section{INTRODUCTION}

The Musée des Confluences/Muséeum d'histoire naturelle in Lyon holds an impressive collection of Predynastic Egyptian mummies, in particular many animal and several human mummies. This collection has been initiated by the two "Lyonnais pioneers" - Louis Lortet and Victor Loret - who aimed to detail this "Nile Valley's PaleoEcology" - as defined by J-Cl Goyon (Goyon, 2007) - by building up an original collection, using both an anthropological and archaeological approaches. To replace these mummies in their cultural context, an absolute chronological framework is required. To this purpose, radiocarbon dating can bring chronological information by the analysis of various organic materials, in particular hair, skin, flesh and fine linen strips. Among this collection, three Predynastic human mummies gave coherent radiocarbon results, showing that they were buried during the Nagadean period.

In contrast, the observation of two other mummies (1626 and 1627) revealed classical embalming traces (nose padding, right side incision) showing that they had undergone a funeral ritual of mummification. The discrepancy of the dating results performed on both textiles and organic materials shows that these mummies' samples are probably being aged by a ${ }^{14} \mathrm{C}$ depleted product. In ancient Egypt, several products were used to embalm bodies: natron was the most common since it was widely employed for many centuries. It was associated with other materials like myrrh, cedar or palm oils and different gums (Ménager et al., 2013). Nonetheless, some Graeco-Roman textual sources testified to the use of bitumen during the embalming ritual by late period Egyptian embalmers. Those attestations lead us to suspect that bitumen could be this radiocarbon depleted polluting substance. Moreover, other studies have already pinpointed the possibility of bitumen utilization in Egyptian embalmed mummies (Conan et Dessort, 1989; Harrel et Lewan, 2002), some of them showing the impact on the radiocarbon dates (Aufderheide et al., 2013). In those studies, GC/MS analyses were used to characterize bitumen.
Extractions using light organic solvent (benzene) were applied on samples before radiocarbon dating, but without given consistent dates.

In order to make bitumen identification possible infrared spectroscopy analyses have been performed on these two embalmed mummies' linen strip samples. Then experiments have been proposed to test the possibility of extracting bitumen from linen textile and so, to radiocarbon date such mummy textile samples. They have been tested on modern linen textiles and divides into four steps: textile soaking in bitumen - linen samples thermal degradation - extraction protocol - infrared analyses and radiocarbon dating at each step. The results of these analyses determine the present state-of-research and the future developments we have to realize in order to restore these two embalmed mummies to their correct chronological context, and more broadly, to systematize radiocarbon dating of Egyptian mummies embalmed with bitumen.

\section{Materials and Methods}

\section{Archaeological samples and modern linen textiles}

Six Egyptian mummies held in the Musée des Confluences of Lyon have been radiocarbon dated by analysing both textile wrappings and organic material (mixed flesh/skin) to ensure the quality of the chronological data. Three Predynastic human mummies coming from the Roda (mummies 2402 and 2403; Lortet and Gaillard, 1909a, p.43-46) and Gebelein necropolis (mummy 2404; Lortet and Gaillard, 1909b) were studied. In particular, an old man and an old woman (respectively 2402 and 2403) excavated from two different undisturbed tombs from Roda have been dated by several analyses on textile and organic material. They were found in similar positions within the tomb, as explained by L. Lortet: "[...] couchées sur le côté gauche, les genoux très relevés contre la région abdominale. Les avants-bras sont ramenés en avant, de telle sorte que les mains se trouvent 
à la hauteur de la face [...]" (Lortet and Gaillard, 1909a, p. 45). Besides, a stem plant found inside a jar excavated in Roda, where an old woman skeleton was discovered (mummy 1252; Lortet and Gaillard, 1909a, p. 39-40), was also analysed. Among the two embalmed mummies, the first one is a child mummy (1626, Figure 1a), sent to the Muséum d'Histoire Naturelle de Lyon by G. Maspero on $10^{\text {th }}$ October 1901 with the mention "Rôda, Hte Égypte". The identification of the second should be confirmed even if it is also considered as a child mummy ${ }^{1}$ (1627, Figure 1b); it entered this collection a few months before, on $16^{\text {th }}$ August 1901 and in the same way, G. Maspero only mentioned "Rôda, Hte Egypte". No more archaeological context is known on these two Egyptian mummies, and both have been kept by the Museum since their reception. No conservation treatments involving chemicals that could be possible pollutants for radiocarbon dating were subsequently performed (only an anoxic treatment is documented).

In order to compare the infrared characteristics of ancient linen samples with the ones from the mummies' strips, a set of four "pure" linen textiles samples (fabric, clothes) from Pharaonic period and held at the Département des Antiquités égyptiennes from the Louvre museum have also been sampled. These textiles had not been used in a funeral context, so had not undergone a funeral embalming ritual. Radiocarbon dating was performed on them to ensure their chronological context, followed by an infrared analysis to provide a signature of pure ancient linen.

Then, since archaeological samples remain precious and scarce, an extraction protocol has been developed to extract bitumen from modern textile samples dipped in this material. Infrared analyses have been performed to check their ability to detect bitumen, and finally, these test-samples have been radiocarbon dated to verify if the efficiency of this new experimental protocol was good enough to totally extract bitumen.

\section{Radiocarbon dating}

Radiocarbon dating has been performed at the Laboratoire de Mesure du Carbone 14 (LMC14, UMS2570 CNRS). Before analysis, samples are physically and/or chemically cleaned to eliminate carbonated contaminations. For organic material, the routine pre-treatment (ABA: Acid-BaseAcid) divides into three successive steps: a first acid wash $(\mathrm{HCl}, 0.5 \mathrm{~N})$ eliminates secondary carbonates deposited

1. A monkey necropolis is also attested near the Rôda necropolis- la Nécropole du dieu Thot-; so this could also be a monkey mummy, Archives du Muséum d'Histoire Naturelle de Lyon, La faune momifiée, Tome 9, 1907. Radiography would help to definitively identify its nature. after the death of the organism, a base wash $(\mathrm{NaOH} 0.1 \mathrm{~N})$ removes humic acids, and then, a final acid wash ensures the
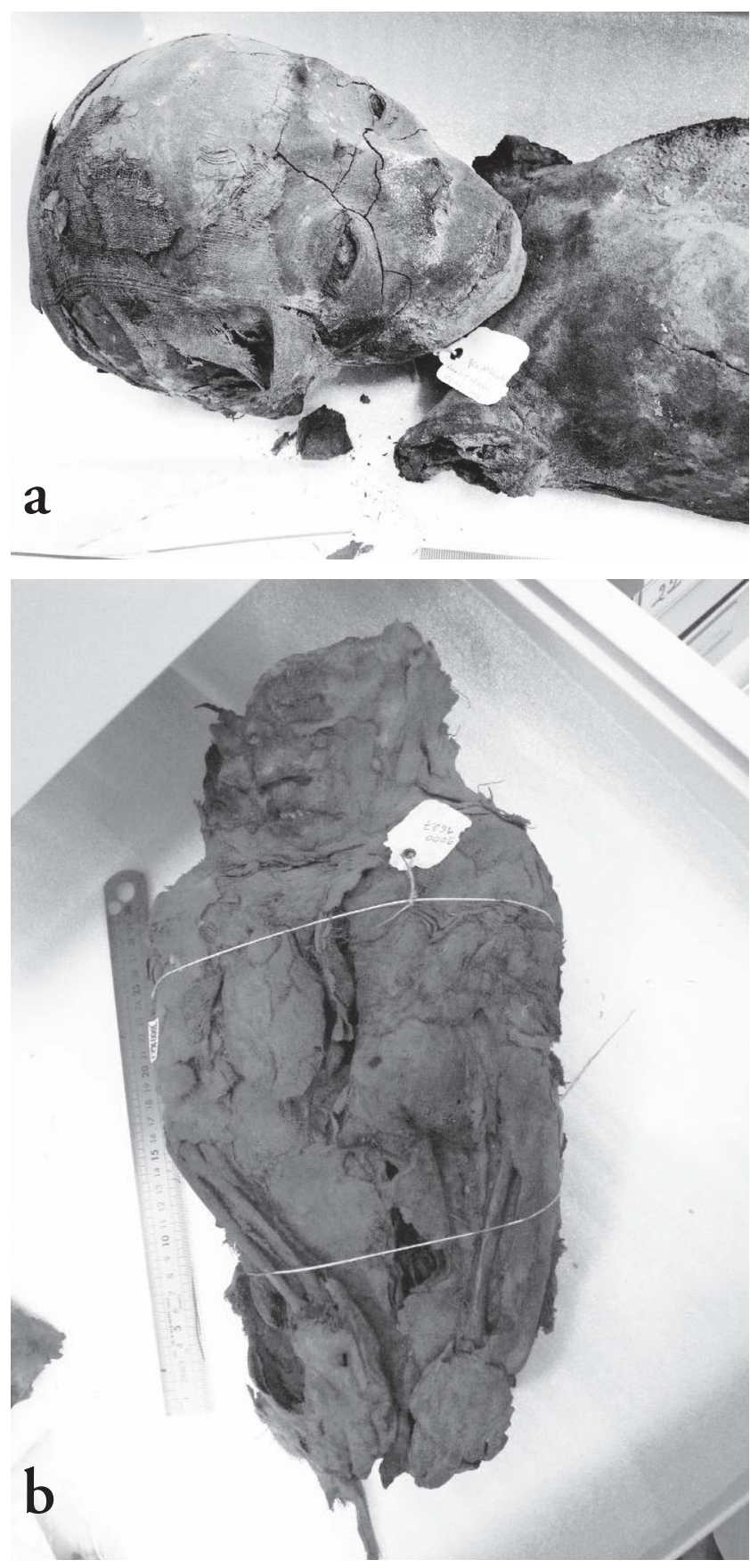

Figure 1: (See colour plate) Children mummies (?) excavated in the Rôda necropolis and presently held at the Musée des Confluences in Lyon: 1626 (a) and 1627 (b).

Figure 1 : (Voir planche couleur) Momies d'enfant (?) mise au jour dans la nécropole de Rôda et actuellement conservées au Musée des Confluences de Lyon: 1626 (a) et 1627 (b). 
removal of dissolved atmospheric carbon dioxide that may have been absorbed during the base wash.

Then, samples are dried and combusted at $900^{\circ} \mathrm{C}$ with $\mathrm{CuO}$ and silver wire. The $\mathrm{CO}_{2}$ formed is collected cryogenically and reduced to graphite over Fe powder in the presence of $\mathrm{H}_{2}$ (Cottereau et al., 2007). The mixture iron/carbon is pressed into a $1 \mathrm{~mm}$ diameter cathode. Measurements have been performed by Accelerator Mass Spectrometry (AMS) on the ARTEMIS facility. Results are given in percent modern Carbon (pMC) and radiocarbon ages (BP), they have been calibrated using OxCal 4.2 software (Bronk Ramsey, 2009), using the IntCal09 calibration curve (Reimer et al., 2009). The same routine chemical pre-treatment (ABA) has been applied on all the samples from mummies 2402, 2404, 1252, 1626 and 1627.

\section{Attenuated Total Reflectance Infra-Red Spectroscopy (ATR-IR)}

Attenuated Total Reflectance Infrared spectroscopy (ATR-IR) analyses have been performed at the MONARIS laboratory (UMR 8233 CNRS-UPMC). ATR-IR spectra were recorded with a Bruker Equinox 55 spectrometer coupled to an IRscope II microscope. An ATR objective is directly mounted on the microscope. It is equipped with a germanium crystal and allows a unique reflection at the crystal/sample interface. The analyzed area is about $60 \mu \mathrm{m}$ with a probing depth of a few micrometers from the sample surface. The ATR objective has a visual mode, which allows the user to choose the area to analyze. 64 scans accumulations with a $4 \mathrm{~cm}^{-1}$ resolution were enough to obtain spectra with a good signal to noise ratio.

\section{Experimental protocol for chemical extraction}

In order to extract the polluting material in which the mummies were dipped, in addition to the routine ABA chemical pre-treatment currently applied for radiocarbon dating, a more aggressive chemical extracting protocol has been developed and tested by the Ingénierie de la restauration des patrimoines naturel et culturel team from the Université d'Avignon (UMR 7263 CNRS - IRD); it derives from (Buckley et al., 2004) but involves more non-polar solvents and is adapted for archaeological matrices, in particular for mummification balms.

To begin with, and as the quantity of archaeological material remained scarce and precious, this experimental protocol has been applied on modern linen textile test-sample. The whole protocol was divided into four steps (figure 2): linen test-samples were locked on a glass slide with a Teflon plate and impregnated with $300 \mu \mathrm{L}$ of a Judean bitumen (from Artech, Avignon, France) solution $\left(30 \mathrm{mg} \cdot \mu \mathrm{L}^{-1}\right)$ in dichloromethane (Step 1). After their drying at ambient temperature, samples were artificially aged in an oven at $60^{\circ} \mathrm{C}$ for 60 days (Step 2), before carrying out the extraction protocol detailed on figure 2 (Step 3). Resulting samples from each step were analysed by infrared spectroscopy and then, radiocarbon dated (Step 4) to evaluate the different treatments' effects.

\section{Results}

\section{Radiocarbon dating of Egyptian mummies}

The set of radiocarbon dates performed on Egyptian mummies 2402, 2403, 2404 is perfectly coherent with what we expected, showing that the three Predynastic mummies were buried during the Nagadean period. Besides, the stem plant found inside a jar excavated in Roda, where an old woman skeleton was discovered (mummy 1252; Lortet and Gaillard, 1909a, p. 39-40), gave a younger age close to the beginning of the Old Kingdom. Nonetheless, this data has to be taken carefully as the association between the woman skeleton and the stem plant remains uncertain. Those results allows for conclusions to be drawn on the possibility of using radiocarbon for dating non-embalmed Egyptian mummies, whatever the kind of organic matter analyzed (table 1).

Nonetheless, the study of the two embalmed mummies (1626 and 1627) shows the difficulty of applying this technique on mummies that have undergone an embalming ritual involving materials, sometimes not well identified, influencing radiocarbon results. Fourteen radiocarbon dates have been performed on these two embalmed mummies (1626 and 1627), using the routine chemical pretreatment $\mathrm{ABA}$; they gave strongly disparate results for each mummy (Table 2). For the mummy 1626, textile is dated between $4673 \pm 25 \mathrm{BP}$ (SacA 22306) and $2772 \pm 28$ BP (SacA 23673) whereas organic material extends from $7455 \pm 31$ (SacA 22305) to $7156 \pm 32$ BP (SacA 22304). In the same way, radiocarbon ages for the mummy 1627 ranges from $3378 \pm 29$ (SacA 23675) to $2153 \pm 21 \mathrm{BP}$ (SacA 22308) for textile samples and from $2241 \pm 22 \mathrm{BP}$ (SacA 22309) to $2218 \pm 26 \mathrm{BP}$ (SacA 23677) for organic material. Thus, the mummy 1626 is dated from 6406 calBC to 841 calBC $(2 \sigma)$ and the mummy 1627 from 1749 calBC

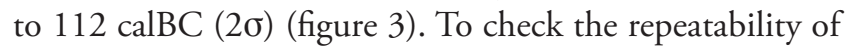
our radiocarbon dates and when we had enough material, a second radiocarbon dating was performed on the same 


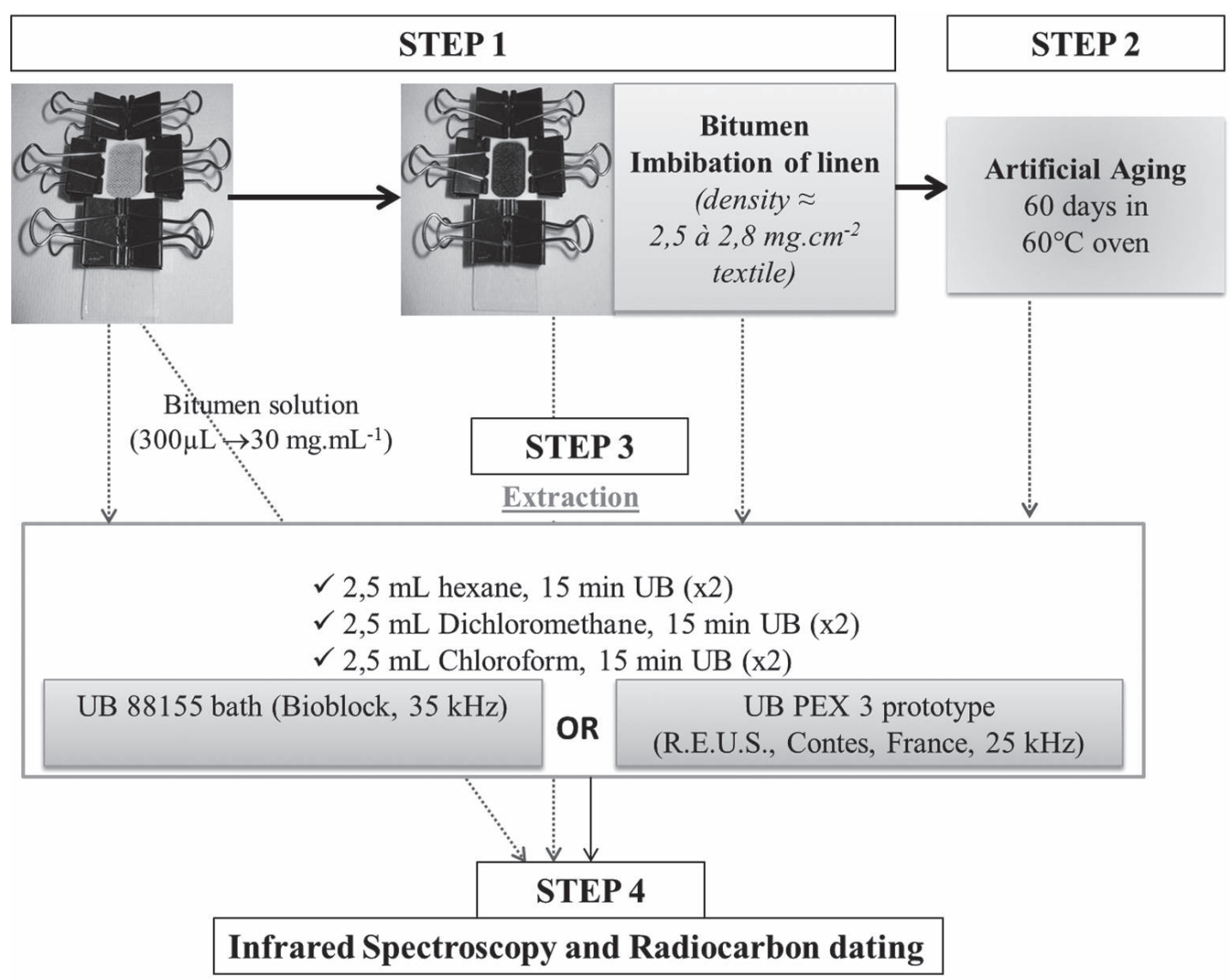

Figure 2: Experimental protocol developed to prepare, extract and analyze the modern linen textile/ bitumen test-sample. It divides into four steps.

Step 1: Impregnation of test-samples in $300 \mu \mathrm{L}$ of Judean bitumen (Artech, Avignon, France) solution $\left(30 \mathrm{mg} \cdot \mu \mathrm{L}^{-1}\right)$. They were locked between a Teflon plate and a glass skip. $10 \mathrm{mg}$ bitumen has been run on.

Step 2: Test-samples have been placed within a $60^{\circ} \mathrm{C}$ oven during 60 days to simulate an accelerated ageing of linen fibres and bitumen. Step 3: Extracting protocol divides into three sub-steps, using three solvents classically used for extracting balms to the organic fraction, and following a non-aggressive gradient:

- An extraction with a $2.5 \mathrm{~mL}$ hexane solution, followed by an ultrasonic bath during $15 \mathrm{~min}$;

- An extraction with a $2.5 \mathrm{~mL}$ dichloromethane solution, followed by ultrasonic bath during $15 \mathrm{~min}$;

- An extraction with a $2.5 \mathrm{~mL}$ chloroform solution, followed by ultrasonic bath during $15 \mathrm{~min}$.

Each step was repeated twice and two different ultrasonic bath systems have been tested: le bath US 88155 (Bioblock, $35 \mathrm{kHz})$ and a prototype US bath PEX 3.

Step 4: Test-samples have been analyzed by infrared spectroscopy and radiocarbon dated.

Figure 2 : Protocole expérimental développé pour préparer, extraire et analyser les échantillons-test de textiles en lin modernes/bitume. Il se divise en quatre étapes.

Étape 1 : Imprégnation des échantillons-test dans $300 \mu \mathrm{L}$ d'une solution de bitume de Judée (Artech, Avignon, France; 30 mg. $\mu L^{-1}$ ). Les échantillons sont bloqués entre un moule de Teflon et une lame de verre, et $10 \mathrm{mg}$ de bitume ont été coulés dessus.

Étape 2 : Les échantillons-test ont été placés dans une étuve à $60^{\circ}$ pendant 60 jours afin de simuler un vieillissement artificiel des fibres de lin et du bitume.

Étape 3: Le protocole d'extraction a été divisé en trois étapes, à partir de trois solvants classiquement utilisés pour extraire les baumes de la fraction organique et suivant un gradient d'agressivité

- Une extraction à partir d'une solution 2,5 mL d'hexane, puis un nettoyage aux ultrasons pendant 15 min

- Une extraction à partir d'une solution 2,5 $\mu \mathrm{L}$ de Dichlorométhane, puis un nettoyage aux ultrasons pendant 15 min

- Une extraction à partir d'une solution de 2,5 $\mu \mathrm{L}$ de chloroforme, puis un nettoyage aux ultrasons pendant 15 min

Chaque étape a été répétée deux fois et deux systèmes d'ultrasons ont été testés : le bain US 88155 (Bioblock, 35 kHz) et un prototype US PEX 3.

Étape 4 : Les échantillons-test ont été analysés par spectroscopie IR et datés par carbone 14. 


\begin{tabular}{|c|c|c|c|c|c|c|c|c|}
\hline Mummy & $\begin{array}{c}\text { Sample } \\
\text { Reference }\end{array}$ & Specie & $\mathrm{mg} \mathrm{C}$ & $\delta 13 \mathrm{C}$ & \multicolumn{3}{|c|}{ Radiocarbon age BP $(1 \sigma)$} & $\begin{array}{c}\text { Calendar range calBC } \\
(2 \sigma, 95.4 \%)\end{array}$ \\
\hline 1252 & SacA 22310 & Plant stem & 0.60 & -28.3 & 4069 & \pm & 25 & $2849-2492$ \\
\hline \multirow{3}{*}{2402} & SacA 22311 & Textile & 1.37 & -24.6 & 4774 & \pm & 26 & $3640-3520$ \\
\hline & SacA 22312 & Textile & 1.13 & -26.3 & 4780 & \pm & 27 & $3641-3520$ \\
\hline & SacA 22313 & Organic material & 1.55 & -29.5 & 4844 & \pm & 36 & $3704-3530$ \\
\hline \multirow{4}{*}{2403} & SacA 22317 & Organic material & 0.60 & -24.8 & 5047 & \pm & 26 & $3948-3781$ \\
\hline & SacA 22318 & Textile & 1.54 & -25.9 & 4946 & \pm & 28 & $3781-3656$ \\
\hline & SacA 22319 & Textile & 1.50 & -23.5 & 5024 & \pm & 28 & $3943-3712$ \\
\hline & SacA 22321 & Textile & 1.20 & -25.7 & 4875 & \pm & 25 & $3701-3638$ \\
\hline \multirow{2}{*}{2404} & SacA 22314 & Textile & 1.10 & -25.5 & 4719 & \pm & 26 & $3632-3377$ \\
\hline & SacA 22316 & Organic material & 0.48 & -23.9 & 4985 & \pm & 26 & $3911-3696$ \\
\hline
\end{tabular}

Table 1: Radiocarbon dating results ( $1 \sigma$ ) obtained on textile and organic material (skin/flesh) for mummies 1252, 2402 and 2403 (Rôda), and 2404 (Gebelein) held at the Musée des Confluences in Lyon. The $\delta^{13} \mathrm{C}$ values are AMS measures.

Tableau 1 : Résultats des datations radiocarbone (1 $\sigma$ ) réalisées sur les textiles et la matière organique (peau, chaire) des momies 1252, 2402,2403 (Rôda) et 2404 (Gebelein) conservées au Musée des Confluences de Lyon. Les valeurs de $\delta^{13} C$ sont des valeurs mesurées par SMA.

sample with the repetition of the entire analysis line (pretreatment-combustion-graphitization-measurement) and so far the results obtained are perfectly accordant with the previous ones (table 2). Therefore, the disparity of the dating results does not rely on the method involved but is due to a polluting material, which has not been extracted by the chemical pre-treatment used. Consequently, the dating results are older than expected, so the polluting material is depleted in ${ }^{14} \mathrm{C}$. This last substance of fossil origin is consistent with an ageing effect suggesting that the polluting product, not correctly extracted by the chemical ABA pre-treatment, could be bitumen. For this study, we decided to focus on the characterization and dating of linen textile samples instead of the other organic materials (hair, skin, flesh) so as to avoid difficulties relating to the separation and identification of the organic contamination.

\section{Infrared spectroscopy analyses on mummies samples}

Infrared spectroscopy analyses have been performed on textile samples of both the embalmed mummies 1626 and 1627 and the Predynastic mummy 2402. About 3 to 5 analyses for each sample have been performed and representative spectra are presented in figure 4 . The infrared spectrum of the embalmed mummies 1626 and 1627 are similar. The spectra can be divided in two regions: (i) the first is around $1480-1780 \mathrm{~cm}^{-1}$ with its maximum at $1705 \mathrm{~cm}^{-1}$; and is assigned to the $\mathrm{C}=\mathrm{O}$ and $\mathrm{C}=\mathrm{C}$ stretching vibrations (Bellamy, 1975; Daher et al., 2010) (ii) the second appears as a double band between 2800 and $3000 \mathrm{~cm}^{-1}$ and is assigned to the
C-H stretching vibrations (Derrick et al., 1999; Daher et al., 2013). For the mummy 2402, the same absorption bands are also visible with different shape: (i) the most intense band of the 1480-1780 $\mathrm{cm}^{-1}$ region is centred on $1638 \mathrm{~cm}^{-1}$ with a quite different profile, (ii) the $\mathrm{CH}$ region does not display such resolute and intense double band between 2800 and $3000 \mathrm{~cm}^{-1}$.

In order to characterize the embalmed material, we had to analyse linen free of contaminant and embalming material. For that purpose, a second set of analyses has been performed on four "pure" linen textiles from the Pharaonic period and held at the Département des Antiquités égyptiennes of the Louvre museum. Dating results are detailed in Table 3 and extend from the First Intermediate Period to the Hellenistic Period.

Figure 5a shows the comparison of the spectra of the four linen textiles from the Pharaonic period and a modern linen sample. The five IR spectra have similar profiles confirming that the four Egyptian textiles are made of linen (Garside and Wyeth, 2003, 2006, Proniewicz et al., 2001, Fanti et al., 2013), whatever their historical period of fabrication. They are characterized by three absorption bands around $850-1210 \mathrm{~cm}^{-1}, 1240-1500 \mathrm{~cm}^{-1}$ and $2800-3000 \mathrm{~cm}^{-1}$. A single band attributed to the $\mathrm{C}-\mathrm{H}$ stretching vibrations characterizes the last one. This single band is characteristic of linen when included in textiles (Garside and Wyeth, 2003, 2006), unlike the vibrational spectra of linen fibres (in their raw state and before any processing), which show a double band in this 2800-3000 $\mathrm{cm}^{-1}$ region (Proniewicz et al., 2001, Fanti et al., 2013). 


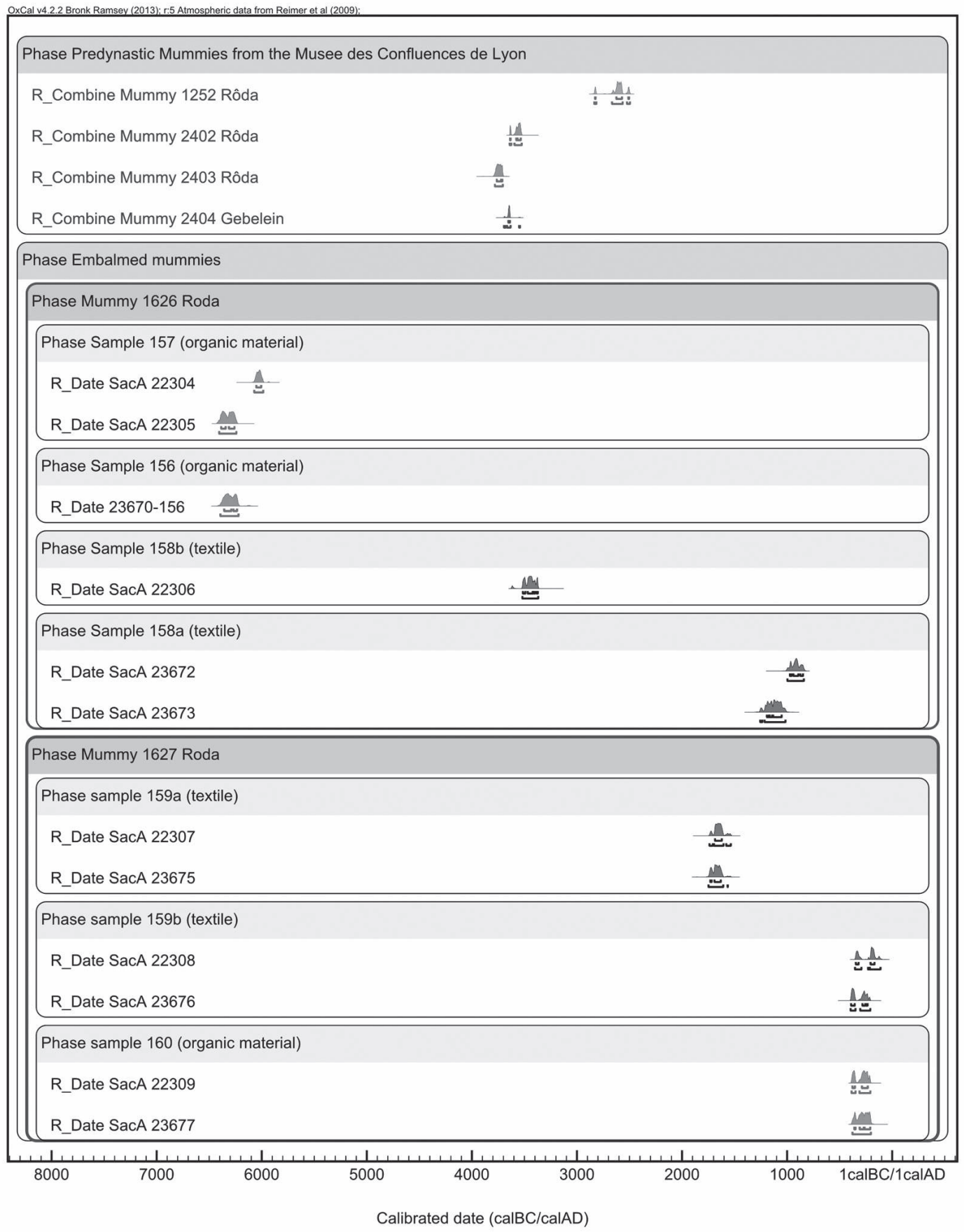

Figure 3: (See colour plate) Results of radiocarbon dating performed on the two embalmed mummies. In the Phase "embalmed mummies", calibrated temporal densities obtained on organic material are in red, whereas those obtained on textile samples are in black. Results are gathered by samples (one phase per sample, 156, 157, 158a, 158b, 159a, 159b, 160), repeated measures on a same sample give the same results, whereas different samples from the same mummies give disparate and incoherent results, extending from 6406 to $841 \mathrm{calBC}(2 \sigma)$ for mummy 1626, and from 1749 calBC to 112 calBC $(2 \sigma)$ for mummy 1627.

Figure 3: (Voir planche couleur) Résultats des datations réalisées sur les deux momies embaumées. Dans la phase "embalmed mummies", les densités d'âge calibrées obtenues sur la matière organique sont en rouge, celles obtenues sur les échantillons de textiles sont en noir. Les résultats sont rassemblés par échantillons (une phase par échantillon 156, 157, 158a, 158b, 159a, 159b, 160), les mesures répétées sur un même échantillons donnent des résultats cohérents, alors que les analyses réalisées sur différents échantillons d'une même momie donnent des résultats incohérents, sétendant de 6406

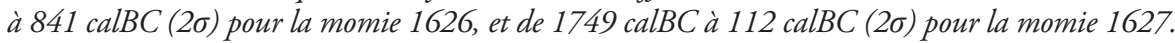




\begin{tabular}{|c|c|c|c|c|c|c|c|}
\hline Mummy & $\begin{array}{l}\text { Sample } \\
\text { reference }\end{array}$ & Specie & $\operatorname{mg~C}$ & $\delta 13 \mathrm{C}$ & \multicolumn{3}{|c|}{ Radiocarbon age $\mathrm{BP}(1 \sigma)$} \\
\hline \multirow{6}{*}{1626} & SacA 22304 & Organic material & 0.35 & -24.1 & 7156 & \pm & 32 \\
\hline & SacA 22305 & Organic material & 1.58 & -25.0 & 7455 & \pm & 31 \\
\hline & SacA 22306 & Textile & 1.05 & -25.1 & 4673 & \pm & 25 \\
\hline & SacA 23670 & Organic material & 1.02 & -23.9 & 7413 & \pm & 40 \\
\hline & SacA 23672 & Textile & 0.85 & -24.8 & 2772 & \pm & 28 \\
\hline & SacA 23673 & Textile & 1.26 & -22.9 & 2922 & \pm & 30 \\
\hline \multirow{6}{*}{1627} & SacA 22307 & Textile & 1.30 & -24.9 & 3359 & \pm & 26 \\
\hline & SacA 23675 & Textile & 1.30 & -24.9 & 3378 & \pm & 29 \\
\hline & SacA 22308 & Textile & 0.50 & -27.0 & 2153 & \pm & 21 \\
\hline & SacA 23676 & Textile & 1.10 & -24.1 & 2263 & \pm & 27 \\
\hline & SacA 22309 & Organic material & 1.60 & -23.7 & 2241 & \pm & 22 \\
\hline & SacA 23677 & Organic material & 1.26 & -23.7 & 2218 & \pm & 26 \\
\hline
\end{tabular}

Table 2: Radiocarbon dating results $(1 \sigma)$ obtained on textile and organic material (skin/flesh) sampled on mummies 1626 and 1627 from the Musée des Confluences of Lyon. The $\delta^{13} \mathrm{C}$ values are AMS measures. Tableau 2 : Résultats des datations radiocarbone $(1 \sigma)$ réalisées sur les textiles et la matière organique (peau, chair) des momies 1626 et 1627 du Musée des Confluences de Lyon. Les valeurs de $\delta^{13} C$ sont des valeurs mesurées par SMA.

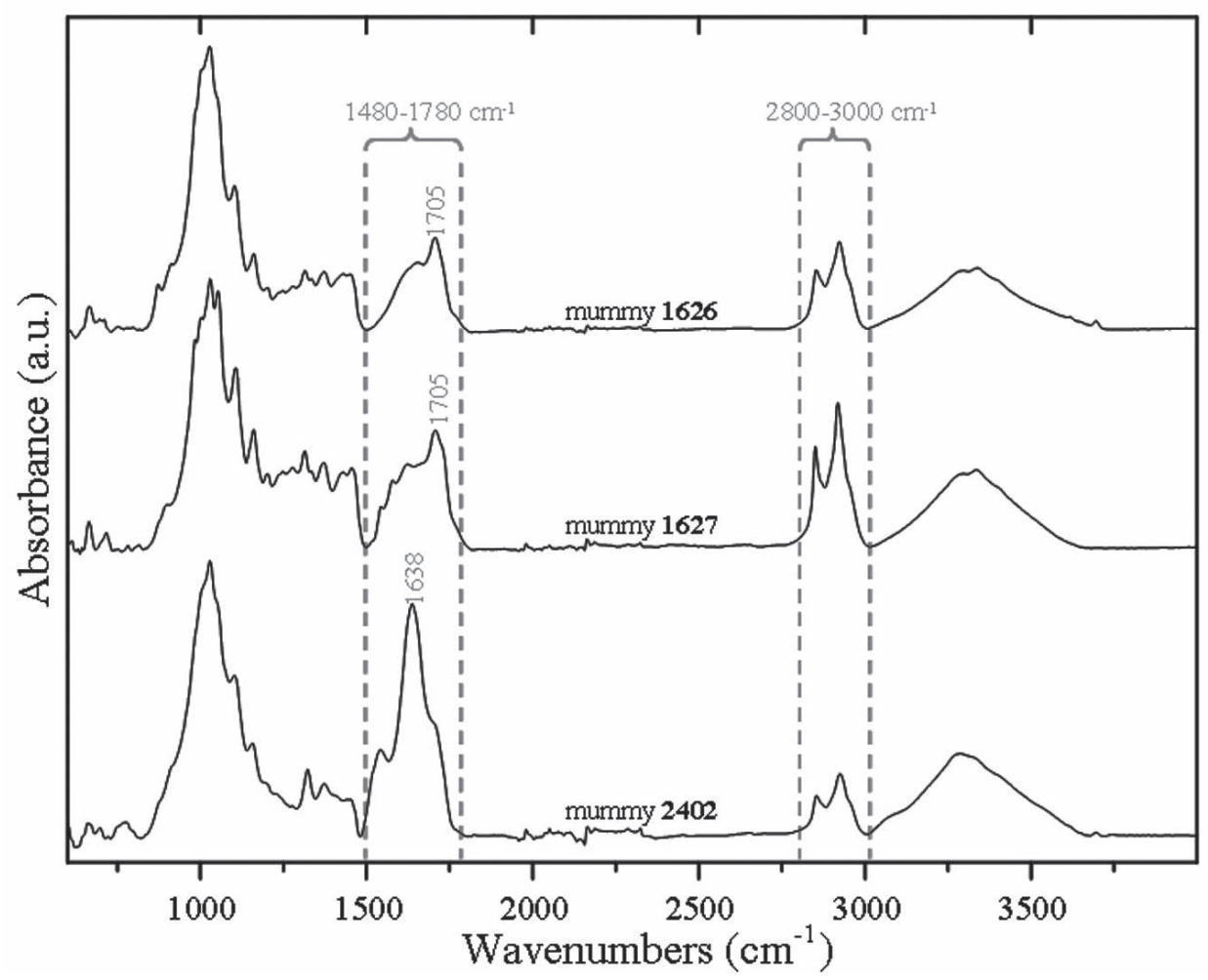

Figure 4: Representative ATR-IR spectra obtained on textile samples from embalmed mummies 1626, 1627 and Predynastic mummy 2402 , underlining a different signature for samples where bitumen is suspected. General profiles are similar for textile taken on embalmed mummies 1626 and 1627 . They are characterized by a large peak around $1480-1780 \mathrm{~cm}^{-1}$ with a single band close to $1705 \mathrm{~cm}^{-1}$; and a double band around 2800-3000 $\mathrm{cm}^{-1}$. Mummy 2402 profile is slightly different: the single band in the first peak has a lower wavenumber at $1638 \mathrm{~cm}^{-1}$ and the double band in the $2800-3000 \mathrm{~cm}^{-1}$ region is less intense.

Figure 4: Spectres ATR-IR obtenus sur les échantillons de textiles des momies embaumées 1626, 1627 et de la momie prédynastique 2402 . Ils montrent une différence de signature pour les échantillons où la présence de bitume est suspectée. Les profils généraux sont similaires pour les textiles provenant des momies embaumées 1626 et 1627 et sont caractérisés par une large bande autour de 1480-1780 $\mathrm{cm}^{-1}$ avec une bande individualisée autour de 1705 $\mathrm{cm}^{-1}$, et une double bande autour de $2800-3000 \mathrm{~cm}^{-1}$. Le profil obtenu sur l'échantillon de la momie 2402 est légèrement différent : le maximum de la première bande présente un nombre d'onde inférieur à $1638 \mathrm{~cm}^{-1}$ et la double bande dans la région $2800-3000 \mathrm{~cm}^{-1}$ est moins intense. 


\begin{tabular}{|c|c|c|c|c|c|}
\hline \multirow{2}{*}{ Sample } & \multicolumn{3}{|c|}{ Radiocarbon dating } & \multirow{2}{*}{ Specie } \\
\cline { 2 - 5 } & Sample Reference & $\begin{array}{c}\text { Radiocarbon age BP } \\
(1 \sigma)\end{array}$ & $\begin{array}{c}\text { Calibrated range } \\
\text { calBC }(2 \sigma)\end{array}$ & Textile \\
\hline Mummy 1626 & - & - & - & $?$ \\
\hline Mummy 1627 & - & - & $3641-3521$ calBC & Textile \\
\hline Mummy 2402 & SacA 22312 & $4780 \pm 27$ & $2140-1976$ calBC & First Intermediate Period & Textile \\
\hline E 13595 & SacA 14688 & $3675 \pm 25$ & $1496-1317$ calBC & New Kingdom \\
\hline AF 11293 & SacA 14695 & $3135 \pm 30$ & $978-827$ calBC & Third Intermediate Period & Textile \\
\hline N 1297 & SacA 14707 & $2755 \pm 30$ & $723-393$ calBC & Hellenistic Period & Textile \\
\hline AF 5230 & SacA 14706 & $2385 \pm 30$ & & Thed \\
\hline
\end{tabular}

Table 3: Linen textiles analysed using ATR-IR spectroscopy. Textiles E 13595, AF 11293, N 1297, AF 5230 are held at the Louvre Museum. Radiocarbon ages given in BP with a $1 \sigma$ range (column 3), calibrated ranges are given in calBC with a $2 \sigma$ range (column 4 ); associated historical periods are given column 5.

Tableau 3: Textiles de lin analysés par ATR-IR. Tissus E 13595, AF 11293, N 1297, AF 5230 sont conservés au musée du Louvre. Les âges radiocarbone sont donnés en $B P$ à $1 \sigma$ (colonne 3), les âges calibrés sont donnés en calBC à $2 \sigma$ (colonne 4); les périodes historiques associées sont données colonne 5.

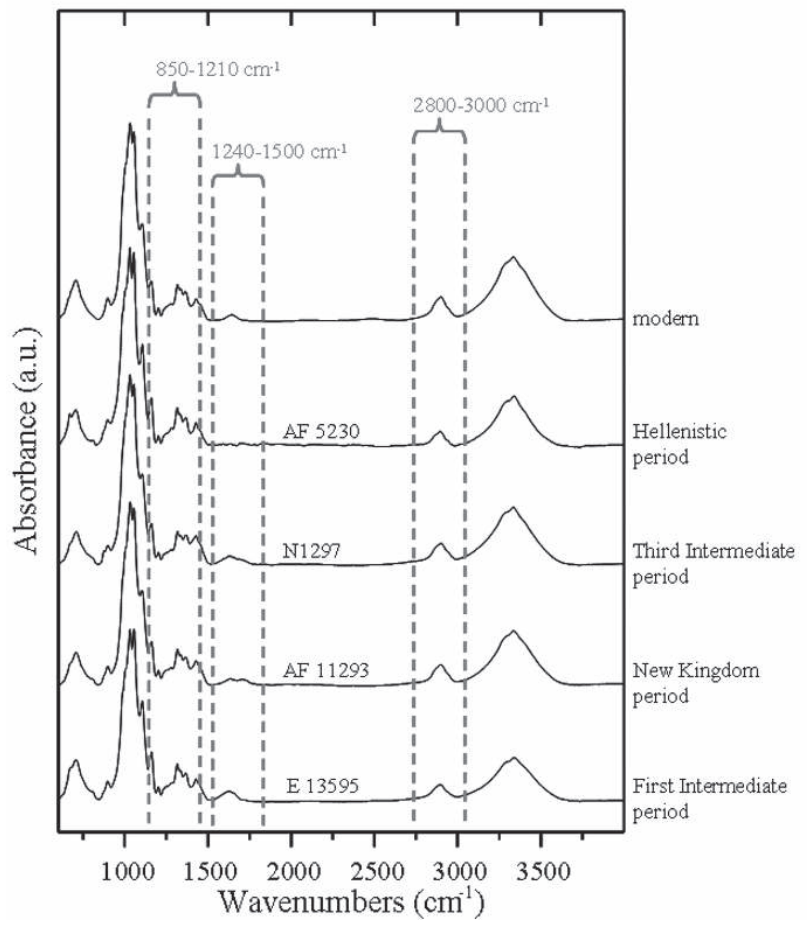

a $\mathrm{b}$

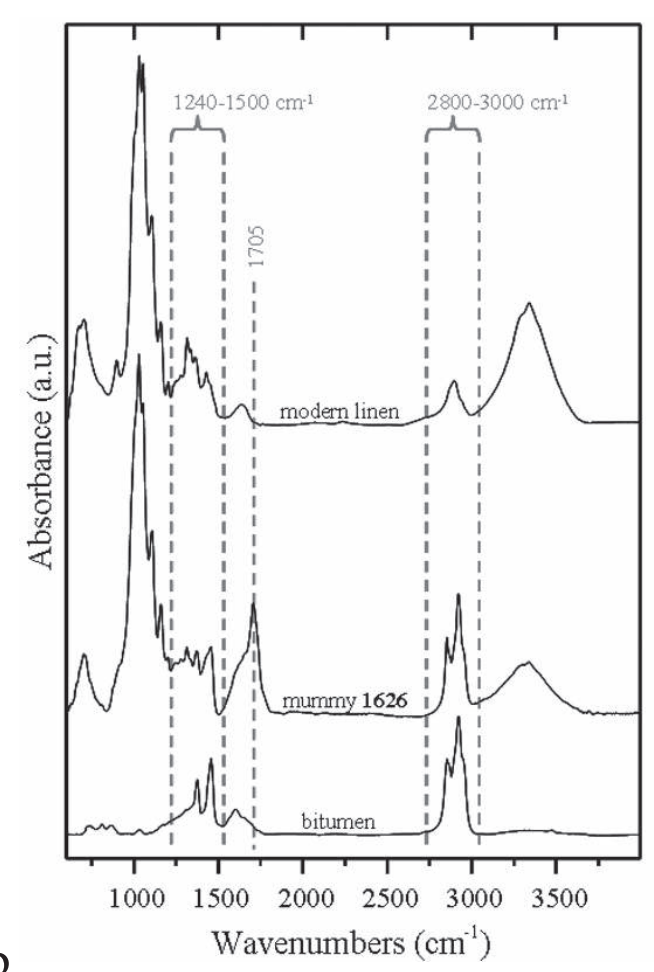

Figure 5: (a) IR spectra obtained for the pure linen textiles held at the Département des Antiquités égyptiennes of the Louvre Museum, and radiocarbon dated from the First Intermediate Period (E 13595) to the Hellenistic Period (AF 5230). The five IR spectra are quasisimilar (b): Comparison of the IR spectra obtained on one pure modern linen textile, on a textile from an embalmed mummy (1626) and on Judean bitumen. The double band in the $2800-3000 \mathrm{~cm}^{-1}$ peak is visible on the embalmed mummy textile as well as on the bitumen spectrum, but is indiscernible on the "pure" linen textile spectrum. Besides, the single band close to $1705 \mathrm{~cm}^{-1}$ is absent of both the bitumen and the pure linen spectra.

Figure 5 (a) : Spectres ATR-IR réalisés sur des tissus "propres » conservés au Département des Antiquités égyptiennes du Louvre et datés par le carbone 14 de la première période intermédiaire (E 13595) à la période hellénistique (AF 5230). Les cinq tissus ont des spectres semblables (b): Comparaison des spectres IR obtenus sur un tissu de lin moderne pur, sur un tissu de momie embaumée (1626) et sur du bitume de Judée. La double bande dans le massif 2800-3000 $\mathrm{cm}^{-1}$, présente sur le spectre de tissu de momie, est aussi présente sur le spectre du bitume alors quelle est absente du spectre de lin pur. Par ailleurs, la bande simple autour de $1705 \mathrm{~cm}^{-1}$ est absente du spectre du bitume et de celui du lin pur moderne. 
The comparison of the spectra of "pure" and embalmed mummies linen (figure $5 \mathrm{~b}$ ) shows differences in the region $1480-1780 \mathrm{~cm}^{-1}$ and $2800-3000 \mathrm{~cm}^{-1}$. In the same way, an ATR-IR analysis has also been carried out on a reference Judean bitumen sample. The corresponding spectrum (figure 5b) is characterized by absorption bands at 1375 , 1455, 2852 and $2925 \mathrm{~cm}^{-1}$.

The modification of the signal at $1240-1500 \mathrm{~cm}^{-1}$ and the bands at 2852 and $2925 \mathrm{~cm}^{-1}$ in the embalmed mummies' spectra confirms the possible presence of bitumen. This would explain the ageing of radiocarbon dates. Nevertheless, a single band is observed around $1705 \mathrm{~cm}^{-1}$ and is only present on embalmed mummies. Such signal is due neither to bitumen nor linen textile (Peters et al., 2005). At this stage of the research, it could be related to the alteration of the archaeological sample over time, the interaction between linen and bitumen, or the use of other embalming materials in conjunction with bitumen.

\section{Chemical Extraction - tests samples}

The experimental protocol described in 1.4 has been tested on modern linen samples. To test the effects of each step of this protocol on radiocarbon dating, eight different samples have been produced. They are listed on Table 4 . They have been observed by binocular microscopy (figure $6)$ : test-sample 2 (step 1) shows the linen textile dipped in bitumen; it could be compared to test-sample 7 (pure linen textile). Test-samples 3 and 4 (steps 1, 2, 3) are more blackened and brighter than test-samples 5 and 6 (steps 1,2), even though the four have undergone the extraction protocol (but the last two have not been artificially aged).

\section{IR analyses on test-samples}

The ATR-IR spectra recorded on the test-samples are presented in Figure 7 and compared to the modern linen and reference bitumen spectra. The major band around 850$1200 \mathrm{~cm}^{-1}$, attributed to linen, is present on the test-samples spectra, excepting for the test-sample 2. The comparison of this sample spectrum with the bitumen one shows that only the representative bands of bitumen (in 1480-1780 and $2800-3000 \mathrm{~cm}^{-1}$ regions) are present in its spectrum. This sample did not undergo the extraction protocol. For spectra from samples 3 and 4 (dipped, degraded and extracted samples), the sharp representative bitumen bands (2852 and $2925 \mathrm{~cm}^{-1}$ ) could be suspected as shoulders on the broad peak centred in this spectral range and attributed to linen. These same bitumen bands do not clearly appear for the samples 5 and 6 (dipped and extracted) and for the samples
7/8 (only linen respectively with and without extraction process) where only the broad linen peak seems to be observed.

The spectra of samples 2, 3 and 4 show an extra feature at $1705 \mathrm{~cm}^{-1}$. The presence of this extra band is not explained at the moment, but is not induced by the extraction solvents (no $1705 \mathrm{~cm}^{-1}$ band in the extracted modern linen). Because this band is only present in the spectra of embalmed mummies (figure $5 \mathrm{~b}$ ) and in the thermally degraded samples 3 and 4 (figure 7), it is clearly associated with the presence of bitumen in aged samples. As the $1705 \mathrm{~cm}^{-1}$ absorption band is absent from non-thermally degraded samples (5 and 6), its presence seems to indicate that a degradation reaction occurs on bitumen/linen association.

\section{Radiocarbon dating of test-samples}

The eight test-samples have been radiocarbon dated. To examine if the classical chemical pre-treatment ABA would provide an efficient cleaning, each test-sample has been shared in two equal portions: test-samples ' $\mathrm{A}$ ' have been directly combusted whereas test-samples ' $\mathrm{B}$ ' underwent the ABA pre-treatment before being combusted. The dating's results are reported Table 4 (column 5) and illustrated in the Figure 8. Test-sample 1's results (Judean Bitumen) are not reported on Figure 8 since they are older than 49,000 $\mathrm{BP}$, as expected. In the same way, test-sample 2 is dated to $930 \pm 28 \mathrm{BP}(2 \mathrm{~A})$ and $1790 \pm 22 \mathrm{BP}(2 \mathrm{~B})$, which confirms the fact that bitumen ages radiocarbon dates, and that $\mathrm{ABA}$ chemical pre-treatment is not sufficient to extract bitumen from linen textile samples. Besides, test-sample 8 (step 2) is modern, which means that the solvents involved in the extraction protocol do not affect radiocarbon dates. Finally, we note that whatever the test-sample studied, adding the ABA pre-treatment does not bring any significant cleaning. Test-samples 3 and 4 (Steps 1, 2, 3), respectively, are dated to $1658 \pm 20 \mathrm{BP}(3 \mathrm{~A}), 1475 \pm 21 \mathrm{BP}(3 \mathrm{~B}), 1895 \pm 60 \mathrm{BP}$ (4A) and $1009 \pm 23 \mathrm{BP}(4 \mathrm{~B})$ : bitumen therefore still remains in those samples despite the extraction they have undergone (new extraction protocol as well as ABA). On the contrary, test-samples 5 and 6 (steps 1,2) are modern: thus for the samples which have not been artificially aged, bitumen has correctly been extracted from the linen fibres.

\section{DisCUSSION AND PERSPECTIVES}

Three major outcomes arise from the present study. First, dating results for test-sample 8 show that the solvents involved in the extraction protocol do not affect the samples' age, so this protocol could be applied without impacting the 


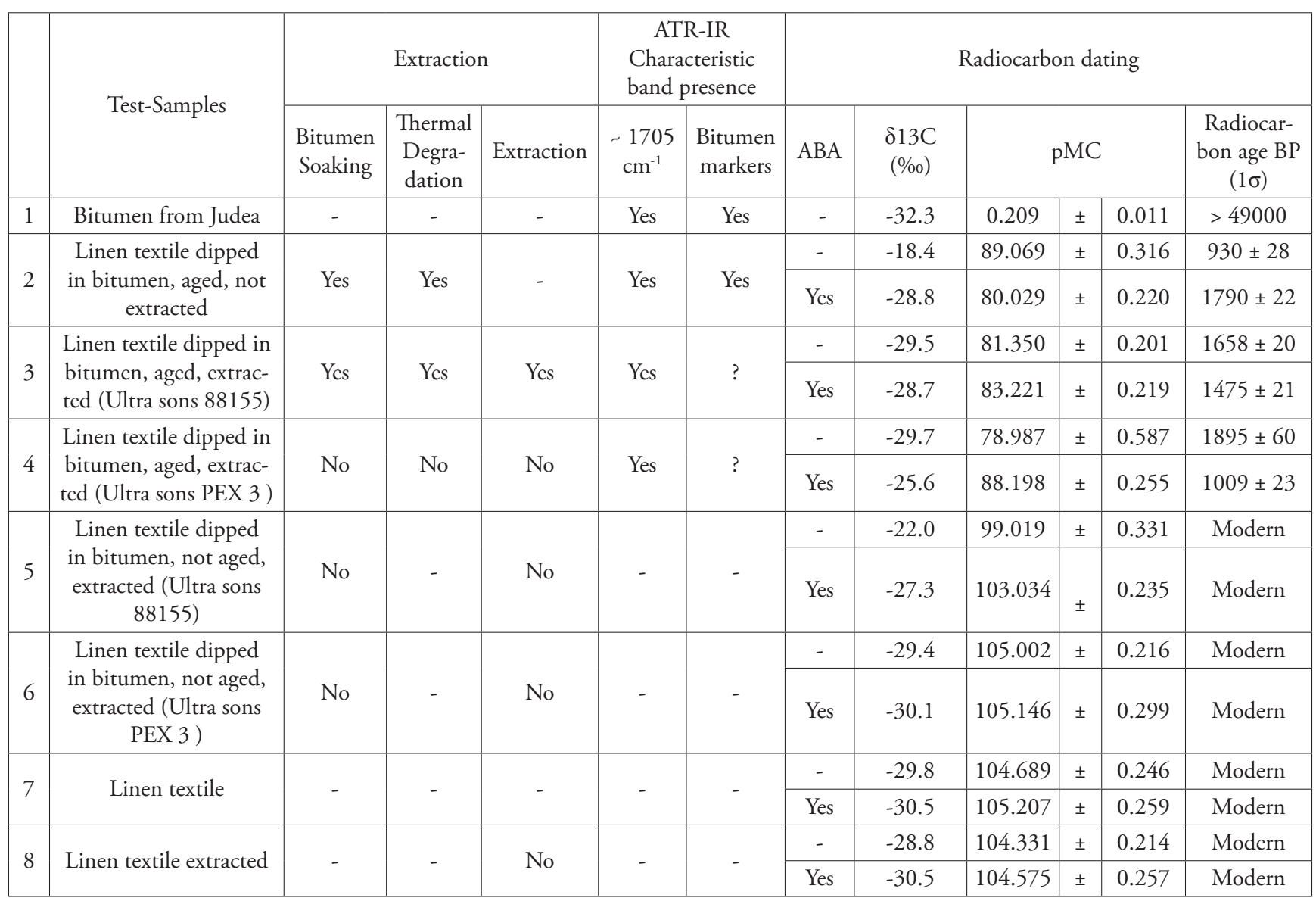

Table 4: Experimental protocol applied on the eight test-samples (column 3); Results of IR analyses, presence of the $1705 \mathrm{~cm}^{-1}$ band, bitumen markers at 1375, 1455, 2822 and $2925 \mathrm{~cm}^{-1}$ (column 4); radiocarbon dating results obtained for the eight test-samples (column 5): ABA pre-treatment, $\delta^{13} \mathrm{C}$-AMS values $( \pm 3 \%$ ), radiocarbon age in $\mathrm{pMC}$ and in $\mathrm{BP}(1 \sigma)$.

Tableau 4 : Protocole expérimental appliqué aux huit échantillons tests (colonne 3); résultats des analyses IR, présence de la bande à $1705 \mathrm{~cm}^{-1}$, identification des marqueurs de bitume 1375, 1455, 2822 et $2925 \mathrm{~cm}^{-1}$ (colonne 4); résultats des datations radiocarbone obtenues sur les huit échantillons tests (colonne 5): pré-traitement $A B A$, valeurs $d u \delta^{13} C-S M A( \pm 3 \%$ ), âge radiocarbone en pMC et en $B P(1 \sigma)$.

radiocarbon dating. Second, all test-samples which have not been artificially aged using a $60^{\circ} \mathrm{C}$ oven, but which have been dipped in bitumen and extracted, are modern. Thus, it shows that this extraction protocol is efficient at extracting "fresh" bitumen impregnation. Third, test-samples that underwent all the experimental protocol and especially the thermal degradation are not modern, so bitumen largely remains on these samples.

Those three remarks lead to the conclusion that the difficulty to extract bitumen is related to effects of time both on the interaction between bitumen and linen fibres, and/ or linen or bitumen alteration, rather than only to bitumen use. We have also noticed that IR spectra of pure linen textile remain stable over time (from First Intermediate Period to Hellenestic one). This suggests linen alteration over time would not be as a satisfactory explanation. Therefore, further investigations have to be conducted to clarify the presence and meaning of the infrared signature around $1705 \mathrm{~cm}^{-1}$, which only appears on the IR spectra of the two embalmed mummies and on the impregnated test-samples that have been thermally degraded.

To answer these questions, different studies will be followed up for this running project. IR analyses will be realized on modern linen textiles dipped in other embalming materials than bitumen (oils, resins...) and then, thermally degraded, to verify if the $1705 \mathrm{~cm}^{-1}$ band is present and being persistent for other organic substances adsorbed by linen. To get a better understanding of the adsorption process of bitumen in linen fibres, a kinetic study will be done by ageing artificially both samples by time and temperature 

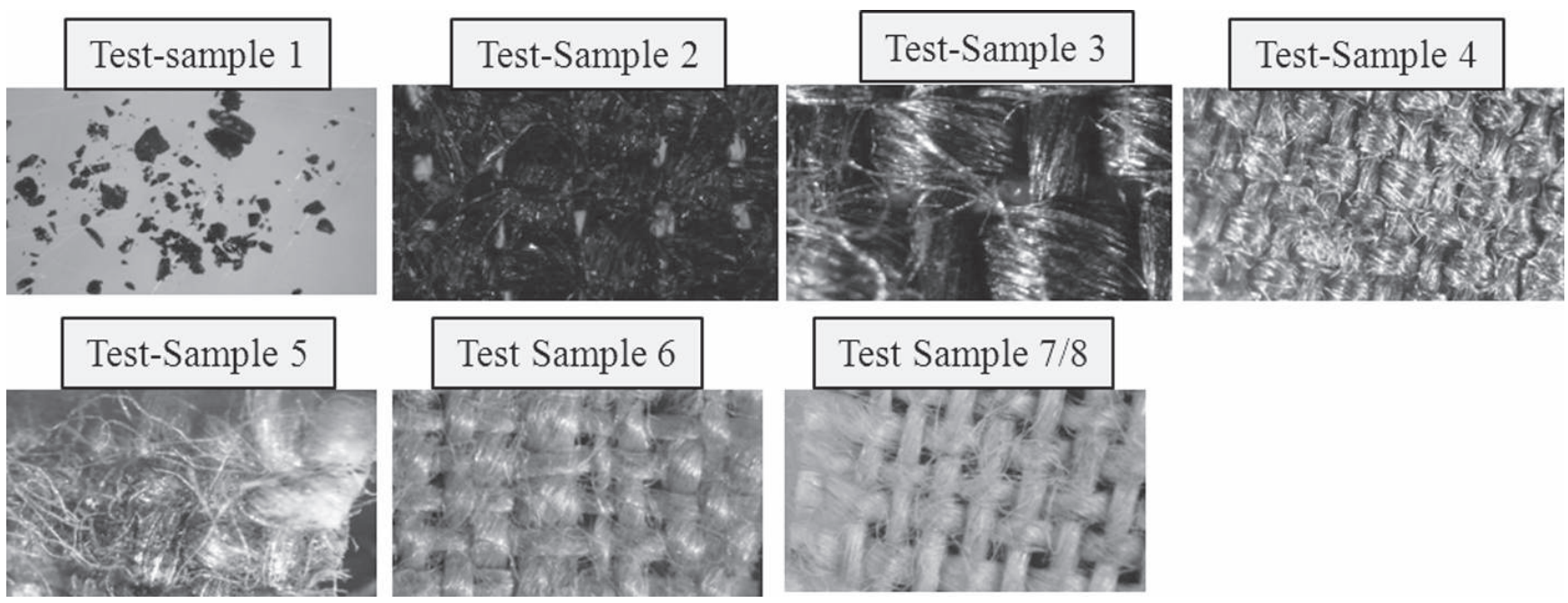

Figure 6: (See colour plate) Binocular microscopy observations of the eight test-samples. Test-sample 7 and 8 have not been dipped in bitumen (7: modern linen; 8: modern linen which undergone the extraction protocol [step 3]). Test-sample 2 shows the linen textile after being dipped in bitumen (step 1). Test-samples 3 and 4 have been dipped in bitumen, thermally degraded and extracted (steps 1, 2, 3); they seems more blackened and brighter than test-samples 5 and 6 , which have been dipped in bitumen and extracted without being thermally degraded (steps 1,2).

Figure 6: (Voir planche couleur) Observation au microscope binoculaire des huit échantillons-test. Les échantillons-test 7 et 8 n'ont pas été imbibés de bitume (7 : lin moderne; 8 : lin moderne extrait qui a subi le protocole d'extraction [étape 3]). L'échantillon-test 2 montre l'état des tissus après l'imprégnation de bitume (étape 1). Les échantillons-test 3 et 4 ont été imbibés, vieillis et extraits (étapes 1, 2, 3) et sont plus noircis et brillants que les échantillons-test 5 et 6 , qui ont été imbibés et extraits sans avoir été vieillis (étapes 1 et 2).

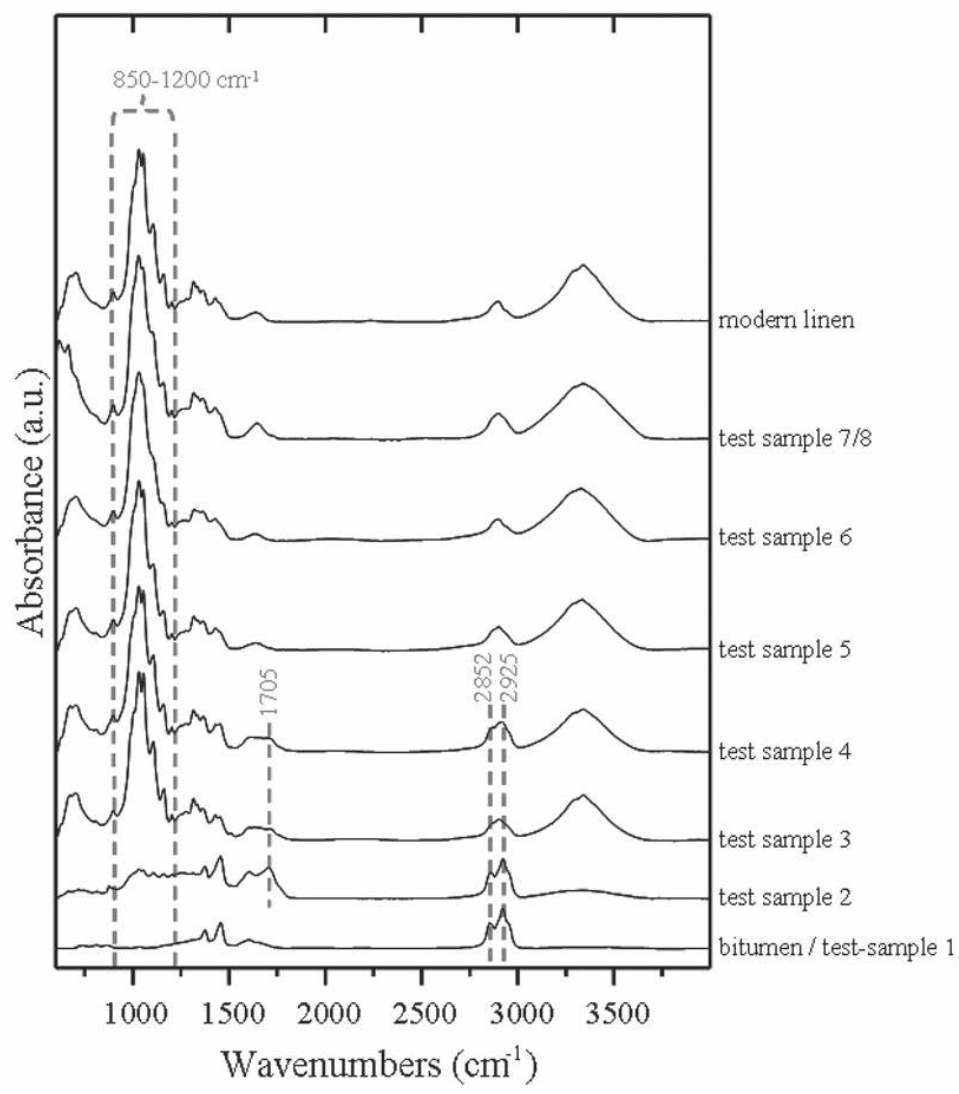

Figure 7: ATR-IR spectra obtained on test-samples 2, 3, 4, 5, 6 and 7/8 compared to pure linen and bitumen ones. Test-samples 2, 3 and 4 (steps 1, 2, 3) spectra have a shoulder at $1705 \mathrm{~cm}^{-1}$ and the double band characteristic of bitumen in the peak $2800-3000 \mathrm{~cm}^{-1}$ is not clearly identifiable, but could not be excluded. On the contrary, testsamples 5 and 6 (steps 1,2$)$ have IR spectra very similar to those of pure line spectra: no shoulder at $1705 \mathrm{~cm}^{-1}$ and a single broad band in the peak $2800-3000 \mathrm{~cm}^{-1}$.

Figure 7 : Comparaison des spectres ATR-IR réalisés sur les échantillons-test 3, 4, 5, 6 et 7/8, à ceux obtenus sur des textiles de lin pur moderne et le bitume. Les spectres des échantillons-test 2, 3 et 4 (étape 1, 2, 3) présentent un épaulement à $1705 \mathrm{~cm}^{-1}$, et la double bande caractéristique du bitume dans le massif 2800-3000 $\mathrm{cm}^{-1}$ n'est pas clairement identifiable, mais ne peut être exclue. Au contraire, les échantillons-test 5 et 6 (étapes 1,2) ont des spectres très similaires au spectre de lin pur: pas d'épaulement à $1705 \mathrm{~cm}^{-1}$ et une bande simple vers $2800-3000 \mathrm{~cm}^{-1}$. 


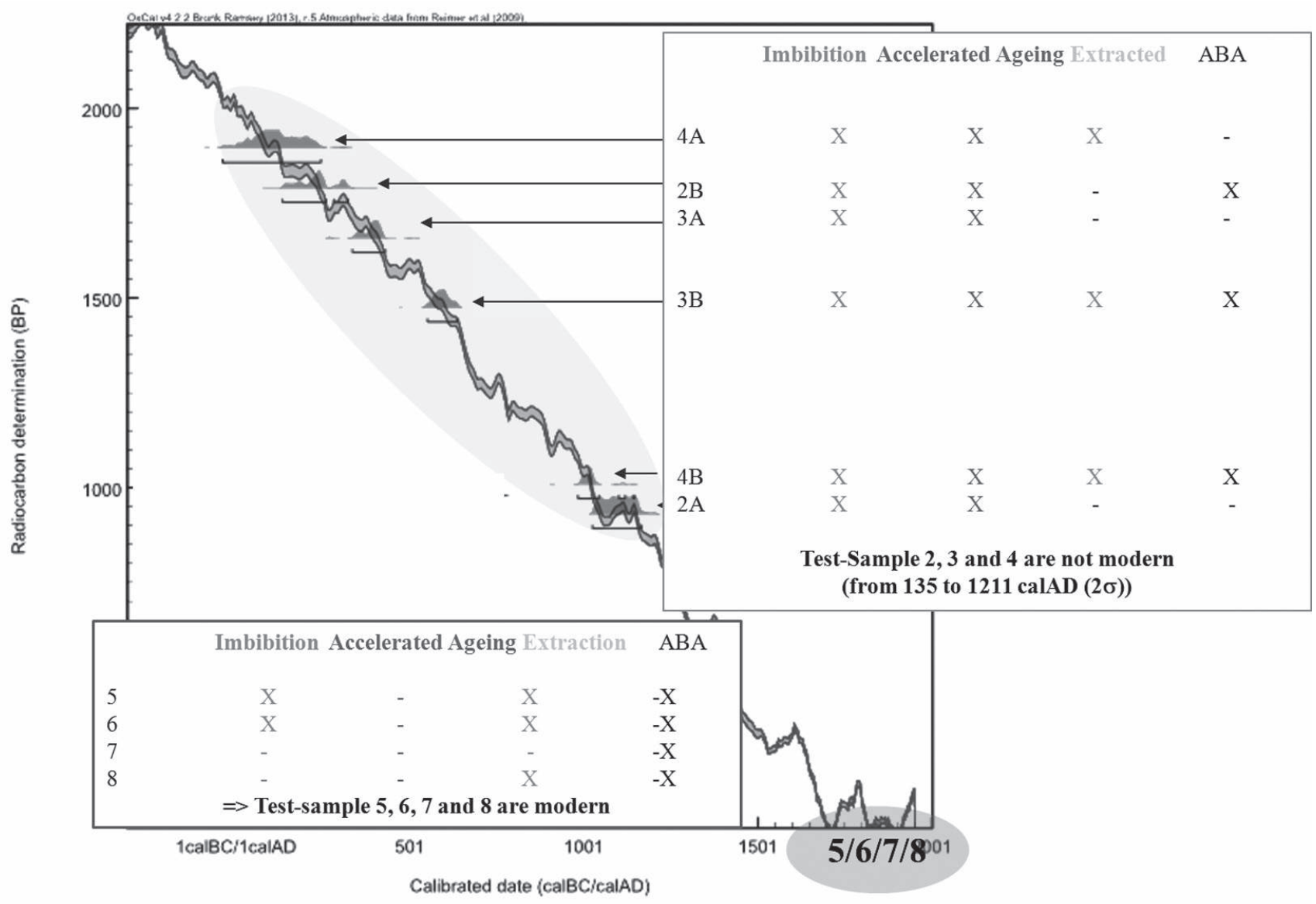

Figure 8: Summary of radiocarbon dating results obtained for the eight test-samples illustrating the potential bitumen extraction (A: samples directly combusted after the experimental extraction protocol; B: samples which have undergone an ABA chemical pre-treatment after extraction). Test-samples 3 and 4 are not modern so all bitumen has not been extracted; test-samples 5 and 6 are modern so all bitumen has correctly been extracted.

Figure 8: Résultats des datations ${ }^{14} C$ réalisées sur les huit échantillons-test illustrant la possibilité d'extraction du bitume ( $A$ : échantillons n'ayant pas subi de prétraitement chimique après l'extraction; $B$ : échantillons ayant subi un prétraitement chimique après l'extraction). Les échantillons 3 et 4 qui ont été imbibés de bitume, vieillis puis extraits ne sont pas modernes, ils contiennent encore du bitume; les échantillons 5 et 6 , qui ont été imbibés de bitume, extraits sans avoir été vieillis, sont modernes : le bitume a bien été extrait de ces échantillons.

gradients. This study will be lead on three different kinds of samples: 1) pure and modern linen textiles 2) modern linen textiles dipped in bitumen 3) pure bitumen samples. For experimentation on the time gradient, samples will be placed in a $60^{\circ} \mathrm{C}$ oven gradually from one week to three months. For experimentation on the temperature gradient, samples will be placed in an oven gradually from $30^{\circ}$ to $100^{\circ}$ during three months. For studying the linen textile natural degradation, further IR analyses will be performed on a larger set of pure Egyptian textiles, radiocarbon dated from the Old Kingdom to the Mamluk period and held at the Département des Antiquités égyptiennes from the Louvre Museum.
At the same time, other extraction protocols will be proposed and tested. First, the present protocol will be improved by using hot solvents to increase their power. According to the radiocarbon results, other solvents will be added in the present protocol like pentane, benzene or carbon disulfide that solubilizes non-mineral fraction of bitumen.

Moreover, more aggressive washes with sodium chlorite solution (bleach treatment) are envisaged to eliminate the most mobile fractions such as lignin, waxes and resins. Finally, extraction of the linen fibres' cellulose could be a third way to investigate (Van Strydonck et al., 2004, Brock et al., 2010). 


\section{Conclusion}

Two embalmed mummies held at the Musée des Confluences in Lyon (1626 and 1627) have been radiocarbon dated (textile and organic material samples) and the results are older than expected, disparate and incoherent while four other Egyptian mummies provide consistent results. The radiocarbon dates' ageing is due to the use of a radiocarbon depleted material involved in the embalming process that is not extracted by chemical pre-treatment routinely used for radiocarbon dating of organic material. Ancient Egyptian sources attest the possibility that embalmers employed bitumen for funeral rituals during the Late Period. This hypothesis is corroborated by IR spectroscopy analyses performed on different embalmed mummies' samples, and compared to "pure" linen textiles from Pharaonic period and to a reference bitumen sample. A first experimental protocol has been developed to extract bitumen from linen textile, and tested on modern linen textile. It divides into four steps: soaking of textile in bitumen - thermal degradation of linen samples - extraction protocol - IR analyses and radiocarbon dating. Eight test-samples have been produced combining the four different steps of the protocol. Radiocarbon dates show that those test-samples dipped in bitumen and extracted without being accelerated ageing are modern, so they do not contain bitumen anymore. On the contrary, the same samples, but which have been thermally degraded, are not modern, so radiocarbon contamination is remaining. Consequently, the difficulty does not rely on the presence of bitumen, but on the process involved between bitumen and linen fibres over time. The following steps of this research project will be to focus on this interaction bitumen/linen over time. New experimentations will be conducted to more precisely characterize it, and then develop a powerful and complete extraction protocol. It will enable us to definitively date these two embalmed mummies and restore them into their cultural context, and then to extend this innovative protocol to the dating of Egyptian mummies embalmed with bitumen.

\section{Acknowledgements}

The authors are indebted to all the LMC14 team for its rigorous work on the radiocarbon samples, to Clara Azémard and Cédric Gobeil for their help in the English translation and thank the two anonymous reviewers whose comments have helped improve the text.

\section{References}

Aufderheide A. C., Nisssenbaum A., Cartmell L., 2004. Radiocarbon date recovery from bitumen-containing Egyptian embalming resin. The Journal of the Society for the Study of Egyptian Antiquities 31.

Bellamy L. J., 1975. The infrared spectra of complex molecules. Vol. 1 (3rd ed.), Halsted Press, a division of John Wiley \& Sons, Inc., New York.

Brock F., Higham T., Ditchfield P., Bronk Ramsey C., 2010. Current pretreatments methods for AMS radiocarbon dating at the OXFORD Radiocarbon Accelerator Unit (ORAU). Radiocarbon 52(1) : 103-112.

Bronk Ramsey C., 2009. Bayesian analysis of radiocarbon dates. Radiocarbon 51(1), p. 337-360.

Buckley S. A., Clark K. A., Evershed R. P., 2004. Complex organic chemical balms of Pharaonic animal mummies. Nature 431 : 294-299.

Connan J., Dessort D., 1989. Du bitume dans les baumes de momies égyptiennes (1295 av. J-C.-300 ap. J. C.) : détermination de son origine et évaluation de sa quantité, Comptes Rendus de l'Académie des Sciences 312 : 1445-1452.

Cottereau E., Arnold M., Moreau C., Baqué D., Bavay D., Caffy I., Comby C., Dumoulin J.-P., Hain S., Perron M., Salomon J., Setti V., 2007. Artemis, the New 14C AMS at LMC14 in Saclay, France. Radiocarbon 49(2) : 291-299.

Daher C., Paris C., Le Hô A.-S., Bellot-Gurlet L., Échard J.-P., 2010. A joint use of Raman and infrared spectroscopies for the identification of natural organic media used in ancient varnishes. Journal of Raman Spectroscopy 41 : 1204-1209.

Daher C., Bellot-Gurlet L., Le Hô A.-S., Paris C., Regert M., 2013. Advanced discriminating criteria for natural organic substances of Cultural Heritage interest: Spectral decomposition and multivariate analyses of FT-Raman and FT-IR signatures. Talanta 115 : 540-547.

Derrick M. R., Stulik D., LANDRY J. M., 1999. Infrared spectroscopy in conservation science scientific-tools for conservation. The Getty Conservation Institute Los Angeles.

Fanti G., Baraldi P., Basso R., Tinti A., 2013. Non-destructive dating of ancient flax textiles by means of vibrational spectroscopy. Vibrational Spectroscopy $67:$ 61-70.

Garside P., Wyeth P., 2006. Identification of Cellulosic Fibres by FTIR Spectroscopy: Differentiation of flax and hemp by polarized ATR FTIR. Studies in Conservation 51 : 205-211.

Garside P., Wyeth P., 2003. Identification of Cellulosic Fibres by FTIR Spectroscopy - Thread and single fibre analysis by attenuated total reflectance. Studies in Conservation 48, p. 269-275.

Goyon J.-C., 2007. Deux pionniers lyonnais de la Paléoécologie de la Vallée du Nil égyptien : Victor Loret (1859-1946) et Louis Lortet (1836-1909). La Constitution de la collection 
égyptienne du muséeum d'Histoire Naturelle de Lyon. Actes du Colloque " Histoire des collections ", Lyon, Avril 2007.

Harrel Lewan, 2002. "Sources of mummy bitumen in ancient Egypt and Palestine "Archaeometry 44, 2 : 285-293.

Lortet L., Gaillard C., 1909a. Archives du muséum d'histoire naturelle de Lyon, La faune momifiée de l'Ancienne Egypte et recherches anthropologiques, Tome 10, Région de Rôda près de Médamout. Lyon, 39-46.

Lortet L., Gaillard C., 1909b. Archives du muséum d'histoire naturelle de Lyon, La faune momifiée de l'Ancienne Egypte et recherches anthropologiques, Tome 10, Gebelein, Lyon, 226-229.

Ménager M., Perraud A., Vieillescazes C., 2013. Analyse de baumes issus de tête momifiée (Thèbes). ArchéoSciences 37 : 7-17.

Peters K. E., Walters C. C., Moldowan J. M., 2005. The Biomarker Guide, Cambridge.

Proniewicz L., Paluszkiewicz C., Weselucha-Birczynska, A., Majcherczyk, H., Baranski, A., Konieczna A., 2001.
FT-IR and FT-Raman study of hydrothermally degradated cellulose. Journal of Molecular Structure 596 : 163-169.

Reimer P. J., Baillie M. G. L., Bard E., Bayliss A., Beck J.W., Blackwell P.G., Bronk Ramsey C., Buck C.E., Burr G.S., Edwards R.L., Friedrich M., Grootes P.M., Guilderson T.P., Hajdas I., Heaton T.J., Hogg A.G., Hughen K.A., Kaiser K.F., Kromer, B., McCormac F.G., Manning S.W., Reimer R.W., Richards D.A., Southon J.R., Talamo S., Turney C.S.M., Van Der Plicht J., Weyhenmeyer C.E., 2009. IntCal09 and Marine09 radiocarbon age calibration curves, 0-50,000 years cal BP. Radiocarbon 51(4) : 1111-1150.

Van Strydonck M., De Moor M., Bénazeth D., 2004. ${ }^{14} \mathrm{C}$ dating compared to art historical dating of Roman and Coptic textiles from Egypt. Radiocarbon 46(1) : 231-244. 